\title{
Parameterization of chlorophyll-specific phytoplankton absorption coefficients for productive lake waters
}

\author{
Birgot PAAVEL, ${ }^{1 *}$ Kersti KANGRO, ${ }^{2,3}$ Helgi ARST, ${ }^{1}$ Anu REINART, ${ }^{2}$ Tiit KUTSER, ${ }^{1}$ Tiina NÕGES ${ }^{3}$ \\ ${ }^{1}$ Estonian Marine Institute, University of Tartu, Mäealuse 14, 12618 Tallinn; ${ }^{2}$ Tartu Observatory, 61602 Tõravere, Tartumaa; ${ }^{3}$ Centre \\ for Limnology, Estonian University of Life Science, 61101 Rannu, Tartumaa, Estonia \\ *Corresponding author: birgot.paavel@ut.ee
}

\begin{abstract}
We examined and parameterized chlorophyll-specific phytoplankton absorption coefficients $\left[\mathrm{a}^{*}{ }_{p h}(\lambda)\right]$ for three turbid productive Estonian lakes on the basis of bio-optical measurements in 2005-2013. A new model parameterization was created that enables to reconstruct the spectra of $\mathrm{a}_{p h}{ }_{p h}(\lambda)$ for turbid productive waters with the higher reliability than previous parameterizations for ocean and coastal waters. The coefficients $\mathrm{A}(\lambda)$ and $\mathrm{B}(\lambda)$ of our model differ from those found in seas, coastal waters and other types of lakes. For any water type separately the increase of total chlorophyll concentration accompanied with the decrease of $\mathrm{a}^{*}$ ph. Our results showed significant seasonal differences between the model parameters due to diversity of the phytoplankton assemblages. This suggests that season-specific models should be developed and validated. Improving the modelling of chlorophyll-specific phytoplankton absorption spectra for hypertrophic lakes is still pending on the availability of a larger dataset, which includes simultaneous measurements of chlorophyll concentrations, phytoplankton absorption coefficients and phytoplankton species composition. Our results implied that total chlorophyll concentration is not a universal predictor of the magnitude of chlorophyll-specific phytoplankton absorption coefficient. The $\mathrm{a}_{\text {ph }}(\lambda)$ models are also likely site and season dependent. Further research is needed for quantifying the role of accessory pigments and other optical constituents as well as the cell size of dominant algal species for considering their influence on the modelling outputs.
\end{abstract}

Key words: Phytoplankton absorption coefficient; in situ data; laboratory analyses; lakes.

Received: January 2016. Accepted: March 2016.

\section{INTRODUCTION}

The underwater light climate is formed as a result of the absorption and scattering of light by optically active constituents: phytoplankton, coloured dissolved organic matter, non-algal particles and water itself. Knowledge of phytoplankton absorption and its dependence on the concentration of chlorophyll- $a$ as well as accessory pigments is fundamental in the refinement of bio-optical models (Arst and Kutser, 1994; Garver and Siegel, 1997; Kutser et al., 2001; Lee and Carder, 2004; Smyth et al., 2006; Pan et al., 2008; Binding et al., 2012). The bio-optical models are used in studying underwater light field but are primarily used in interpretation of remote sensing data. Many authors use the models to develop different bandratio type algorithms (as collection sufficient amount of in situ data is too time consuming and expensive), but model inversion techniques retrieving chlorophyll-a, coloured dissolved organic matter (CDOM) and suspended matter concentration simultaneously are becoming more and more popular in aquatic remote sensing.

The chlorophyll-specific phytoplankton absorption coefficient $\left[a_{\mathrm{ph}}^{*}(\lambda)\right.$ - the amount of light absorbed by a unit of pigment quantity at different wavelengths] provides also information on phytoplankton community structure and is regarded as a key input parameter in primary pro- duction models (Longhurst et al., 1995; Westberry et al., 2005; Arst et al., 2008).

Decades of field studies have shown that $a_{\mathrm{ph}}^{*}(\lambda)$ decreases with increasing chlorophyll concentrations due to the combined influence of the pigment composition and the so-called package effect (Yentsch and Phinney, 1989; Bricaud et al., 1995, 2004; Allali et al., 1997; Lohrenz et al., 2003; Stæhr et al., 2004). This effect depends both on algal cell size and intracellular pigment concentration, which in turn vary with the environmental factors: light availability, temperature and nutrient supply. Typically, eutrophic waters are dominated by large cells that harvest light with higher efficiency than small cells, which tend to be predominant in oligotrophic waters (Duysens, 1956). Differences in the shape of phytoplankton absorption spectra, however, refer to the changes in intracellular pigment composition (Stuart et al., 1998; Ciotti et al., 2002; Babin et al., 2003; Bricaud et al., 2004).

The spatial and temporal heterogeneity in the absorption and scattering properties of phytoplankton (Ahn et al., 1992; Kutser et al., 2006; Metsamaa et al., 2006) predicts that significant errors have to be expected if spectral bio-optical models are not optimized for a particular region or season. One possible approach to resolve this problem is to use parameterization of $a_{\text {ph }}^{*}(\lambda)$ variability. 
Bricaud et al. (1995) recommended to represent $a_{\mathrm{ph}}^{*}(\lambda)$ as a power function of total chlorophyll concentration (TChl - chlorophyll- $a$ concentration including its metabolite phaeophytin- $a$ ):

$$
a_{\mathrm{ph}}^{*}(\lambda)=A(\lambda) \cdot[T C h l]^{-B(\lambda)}
$$

where $A(\lambda)$ and $B(\lambda)$ are wavelength-specific coefficients estimated from the measurements of optical properties of different algal species. The coefficient $A$ reflects $a_{\text {ph }}^{*}$ per $T C h l$ unit, while exponent $B$ reflects deformations of $a_{\mathrm{ph}}^{*}$ spectrum with the increase of TChl. The dataset of Bricaud et al. (1995) included 815 spectra from oceanic waters, where total chlorophyll concentration ranged between 0.02 and $25 \mathrm{mg} \mathrm{m}^{-3}$.

Strömbeck (2001) re-investigated this model for three relatively clear Swedish lakes and brackish archipelago waters near Stockholm. His parameterization covered almost the same range of total chlorophyll concentrations $\left(0.8-33.1 \mathrm{mg} \mathrm{m}^{-3}\right)$ and the results were only a little different: the new $A$ and $B$ had at some wavelengths higher and at some wavelengths slightly lower values than those published by Bricaud et al. (1995). Stæhr and Markager (2004) provided a linear model of ln-transformed data for predicting $a_{\mathrm{ph}}^{*}(\lambda)$ from total chlorophyll concentration. Their main goal was to elaborate the appropriate formula for a wider $T C h l$ range $\left(0.03-88.1 \mathrm{mg} \mathrm{m}^{-3}\right)$ in estuarine, coastal and oceanic waters. However, only two of their study sites among twenty had total chlorophyll concentrations above $22.2 \mathrm{mg} \mathrm{m}^{-3}$. Lately, a similar approach has been used also for 15 lakes in southern Finland (Ylöstalo et al., 2014), where TChl were in same range (Tab. 1). Ficek et al. (2012) and Yoshimura et al. (2012) proposed a $a_{\mathrm{ph}}^{*}(\lambda)$ parameterizations for productive lake waters, where $T C h l$ values reached $336 \mathrm{mg} \mathrm{m}^{-3}$. However, their new $a_{\mathrm{ph}}^{*}$ spectra did not correspond to each other. The model of Yoshimura et al. (2012) represented intensive pigment packaging in the region of $460-500 \mathrm{~nm}$, while in the model of Ficek et al. (2012) the package effect was surprisingly weak, especially at maximum $a_{\mathrm{ph}}^{*}(\lambda)$ in blue and red wavelength regions.

Our attempts to apply the above mentioned models for describing of $a_{\mathrm{ph}}^{*}(\lambda)$ in some cyanobacteria-dominated lakes in Estonia were unsuccessful. Cyanobacteria are very common in lakes but rare in sea waters where the above mention models were parametrised. The accessory pigments of cyanobacteria, such as phycocyanin, has absorption properties that are different from those considered in the models parametrized for sea water (Kutser $e t$ al., 2006; Metsamaa et al., 2006). Also the physical and chemical conditions of inland waters are different from those in ocean, estuarine and coastal waters and that can influence the performance of the marine models in lakes.

Most of the parameterization algorithms for $a_{\mathrm{ph}}^{*}(\lambda)$ are directed to the determination of $A(\lambda)$ and $B(\lambda)$ in the formulae similar to eq. 1 . As the existing models for $a_{\mathrm{ph}}^{*}(\lambda)$ do not perform sufficiently well in eutrophic lake environment, the main aim of present study was to determine new $A(\lambda)$ and $B(\lambda)$ values for eq. 1 that could be used for productive turbid lakes. To achieve this goal, we used the data from three turbid productive lakes in Estonia to examine $T C h l$-specific phytoplankton absorption and parameterized a simple model for describing it spectrally.

\section{METHODS}

\section{Description of lakes}

We studied three turbid productive Estonian lakes Peipsi, Võrtsjärv and Harku during ice-free periods (MayOctober) in 2005-2009 and 2011-2013. In situ and laboratory data were collected from 155 measurement points. Main morphometric characteristics, Secchi depth and optically active constituents of the studied lakes are shown in Tab. 2 .

The submeridionally elongated Lake Peipsi (maximum length approximately $150 \mathrm{~km}$ and width $42 \mathrm{~km}$ ) on the border of Estonia and Russia is shallow, turbid, biologically productive and surrounded by many wetland areas along its coast. The lake consists of three limnologically different parts: 1) the northernmost, largest and deepest $\left(2611 \mathrm{~km}^{2}\right.$, mean depth $8.3 \mathrm{~m}$ ) Lake Peipsi sensu stricto is moderately eutrophic; 2) the southern part, Lake Pihkva $\left(708 \mathrm{~km}^{2}\right)$ is shallower (3.8 $\mathrm{m})$ and hypertrophic; 3 ) very narrow straitlike Lake Lämmijärv $\left(236 \mathrm{~km}^{2}, 2.3 \mathrm{~m}\right)$, connecting the former basins, has some dyseutrophic features (Nõges, 2001).

Tab. 1. The models of chlorophyll-specific phytoplankton absorption coefficient for lakes and selected ocean and coastal waters with the ranges of total chlorophyll concentration (TChl).

\begin{tabular}{llc} 
Author & Study site & TChl $\left(\mathrm{mg} \mathrm{m}^{-3}\right)$ \\
Bricaud et al., 1995 & Oceanic waters & $0.02-25.0$ \\
Strömbeck, 2001 & Archipelago waters near Stockholm and 3 relatively clear Swedish lakes & $0.83-33.1$ \\
\hline Stæhr and Markager, 2004 & Estuarine, costal and oceanic waters & $0.03-88.1$ \\
Ficek et al., 2012 & 15 Pomeranian lakes, Poland & $1.20-336.0$ \\
\hline Yoshimura et al., 2012 & Lake Kasumiguara, Japan & $36.6-214.4$ \\
Ylöstalo et al., 2014 & 15 boreal lakes, southern Finland & $1.80-94.7$ \\
\hline
\end{tabular}


While the access to Lake Pihkva (belongs almost entirely to Russia) is restricted by border regulations, no optical data were available for this part of the lake.

The phytoplankton community in Lake Peipsi is typical for large lowland lakes having some similarities to lakes Ladoga, Onega, Vänern and Vättern (Laugaste et al., 2008). Spring phytoplankton communities of Lake Peipsi are dominated by fast-growing species (diatoms, chrysophytes and cryptophytes), which are adapted to the steep gradients in temperature and light conditions. In Lake Peipsi s.s., the main species are Aulacoseira islandica (O. Müller) Simonsen and Stephanodiscus neoastraea Håk et Hickel whereas in Lämmijärv Cyclotella spp. and Aulacoseira ambigua (Grun. in Van Heurck) Simonsen are abundant (Alikas et al., 2010; Laugaste et al., 2010). In summer, the succession of cyanobacteria starts with Anabaena, then Gloeotrichia echinulata (J. S. Smith) P. Richter appears, followed by species of Microcystis. Aphanizomenon flos-aquae (L.) Ralfs prevails in the cyanobacterial community in AugustSeptember and in warm autumns even until November (Laugaste et al., 2008, 2013). As cyanobacteria typically contain accessory pigments (Stomp et al., 2007), the absorption properties measured in the present study characterize not only chlorophyll but also other pigments. Also note that $T C h l$ in our study means a sum of concentrations of chlorophyll- $a$ and its metabolite phaeophytin- $a$.

Lake Võrtsjärv is a large and shallow non-stratified eutrophic lake in Central Estonia, well mixed by surface waves and currents. The lake has six main inflows, the outflowing River Emajõgi carries the waters to Lake Peipsi. Due to the restricted outflow, large seasonal and annual fluctuations of the water level are one of the most characteristic features of Lake Võrtsjärv. The absolute water level range of $3.1 \mathrm{~m}$ corresponds to a 2.4 -fold difference in the mean depth affecting strongly the underwater light climate
(Nõges and Nõges, 2012). Phytoplankton biomass is substantially higher in low-water years due to better water column illumination and increased release of phosphorus from resuspended bottom sediments (Nõges et al., 2003). Phytoplankton community in Lake Võrtsjärv is dominated by diatoms and cyanobacteria, accounting for more than twothird of the biomass during the ice-free period from May to October. The most common diatoms are from the genera of Aulacoseira and Cyclotella, cyanophytes are composed of Limnothrix planktonica (Woloszyńska) Meffert and Limnothrix redekei (Van Goor) Meffert, which are accompanied by Planktolyngbya limnetica (Lemmermann) Komárková-Legnerova et Cronberg. Cryptophytes and chrysophytes may become exceptionally abundant during a short period in spring (Nõges et al., 2010).

Lake Harku is located $3 \mathrm{~km}$ from the sea on the western border of the Estonian capital Tallinn $\left(59^{\circ} 25^{\prime} \mathrm{N}, 24^{\circ}\right.$ $37^{\prime}$ E). Situated among the agricultural- and grasslands, the lake has received considerable nutrient enrichment and sewage runoff over the last 50 years of the $20^{\text {th }}$ century (Lepane et al., 2004). During the growing season Lake Harku is characterized by heavy algal blooms, with extraordinarily high values of chlorophyll and total suspended matter concentrations: $398 \mathrm{mg} \mathrm{m}^{-3}$ and $82 \mathrm{~g} \mathrm{~m}^{-3}$, respectively (Paavel, 2008). Spring phytoplankton in Harku composed of small-celled green algae from the genera Pediastrum ( $P$. duplex Meyen, $P$. boryanum Meneghini) and Scenedesmus (S. opoliensis P. Richter, $S$. acuminatus Chodat, $S$. spinosus Chodat), while in summer mainly coccal forms of cyanobacteria Microcystis (M. wesenbergii Komárek, M. viridis Lemmermann) are abundant (Erm et al., 2002).

\section{Samples collection and laboratory analyses}

Water samples were collected from the surface layer $(0.2 \mathrm{~m})$ with a standard Ruttner water sampler (Hydrobios

Tab. 2. Morphometric data and bio-optical parameters of studied turbid Estonian lakes.

\begin{tabular}{lccc} 
Parameter & Peipsi & Võrtsjärv & Harku \\
Area $\left(\mathrm{km}^{2}\right)$ & 3555 & 270 & 1.64 \\
Mean depth $(\mathrm{m})$ & 7.0 & 2.8 & 1.6 \\
\hline Maximum depth $(\mathrm{m})$ & 15 & 6.0 & 2.5 \\
TChl $\left(\mathrm{mg} \mathrm{m}^{-3}\right)$ & $19.8 \pm 13.0$ & $51.2 \pm 14.2$ & $160.3 \pm 85.1$ \\
\hline Chl-a $\left(\mathrm{mg} \mathrm{m}^{-3}\right)$ & $16.5 \pm 11.6$ & $44.3 \pm 12.8$ & $132.6 \pm 64.8$ \\
Phaeophytin-a $\left(\mathrm{mg} \mathrm{m}^{-3}\right)$ & $3.5 \pm 2.8$ & $5.9 \pm 4.6$ & $26.4 \pm 42.6$ \\
\hline TSM $\left(\mathrm{g} \mathrm{m}^{-3}\right)$ & $7.4 \pm 4.8$ & $17.2 \pm 5.8$ & $36.2 \pm 15.7$ \\
$a_{\mathrm{ph}}(440)\left(\mathrm{m}^{-1}\right)$ & $0.5 \pm 0.3$ & $1.4 \pm 0.4$ & $3.5 \pm 1.6$ \\
$a_{\mathrm{CDOM}}(380)\left(\mathrm{m}^{-1}\right)$ & $9.1 \pm 3.0$ & $9.3 \pm 2.3$ & $13.7 \pm 3.5$ \\
Secchi depth (m) & $1.5 \pm 0.6$ & $0.7 \pm 0.3$ & $0.4 \pm 0.2$ \\
\hline
\end{tabular}

Chl-a, concentration of chlorophyll-a; TSM, concentration of total suspended matter; Phaeophytin-a, concentration of phaephytin-a; Secchi depth, relative water transparency; TChl, chlorophyll-a concentration including its metabolite phaeophytin- $a ; a_{p h}(440)$, absorption coefficient of phytoplankton at wavelength $420 \mathrm{~nm} ; a_{\text {СDOM }}(380)$, absorption coefficient of coloured dissolved organic matter at wavelength $420 \mathrm{~nm}$. 
$\mathrm{GmbH}$, Kiel, Germany) and stored in the dark and cold for less than $10 \mathrm{~h}$ before filtering. Depending on particle concentration in the water 0.1-1 litre was filtered through GF/F-filters (Whatman). Phytoplankton pigments were extracted from the filters with $96 \%$ ethanol at $20^{\circ} \mathrm{C}$ for 24 hours and measured spectrometrically (Hitachi Ltd., Tokyo, Japan; Spectrophotometer model U-3010) both before and after acidification with dilute hydrochloride acid (ISO, 1992). Later, optical density values were converted respectively to chlorophyll- $a$ and phaeophytin- $a$ concentrations according to Lorenzen (1967) formulas. The sum of chlorophyll-a and phaeophytin-a concentrations is later called as total chlorophyll concentration and abbreviated as TChl.

The absorption coefficients of total particulate and non-algal material retained on GF/F filters were determined respectively before and after pigment bleaching with sodium hypochloride (Ferrari and Tassan, 1999) following the transmittance-reflectance technique (Tassan and Ferrari, 1995, 2002). Filters were scanned with a $2 \mathrm{~nm}$ step in wavelength region $400-700 \mathrm{~nm}$ using a dual beam UV-Visible spectrophotometer (Hitachi U-3010) equipped with an integrating sphere (60INTEGRATING SPHERE ACCY model 130-0632). Compared with the standard transmittance method, the integrating sphere attachment to a dual beam spectrometer offers a remarkable advantage, allowing the accurate correction for light backscattering by the particles. It should be considered, however, that the GF/F filter itself also strongly scatters light and therefore the absorption of a particle-filter aggregate is greater than in situ absorption of suspended particles. This phenomenon is called pathlength amplification and its correction is based on the empirical relationship of the optical density of particles in suspension and the optical density of the same amount of particles retained on GF/F filters (Tassan and Ferrari, 1995):

$$
D_{\text {susp }}(\lambda)=0.423 D_{\text {filter }}(\lambda)+0.479\left(D_{\text {filter }}(\lambda)\right)^{2} \quad \text { (eq. 2) }
$$

The spectral absorption of total particulate material $\left[a_{\mathrm{p}}(\lambda)\right]$ and of non-algal particles $\left[a_{\mathrm{NAP}}(\lambda)\right]$ were calculated respectively from the optical densities of unbleached and bleached and the difference between them was assumed to reflect the absorption of phytoplankton pigments $\left[a_{\mathrm{ph}}(\lambda)\right]$ :

$$
a_{\mathrm{p}}(\lambda)=\frac{2.303 D_{\text {susp }}(\lambda)}{V_{\text {filter }} / A_{\mathrm{c}}},
$$

$$
a_{\mathrm{ph}}(\lambda)=a_{\mathrm{p}}(\lambda)-a_{\mathrm{NAP}}(\lambda)
$$

The coefficient 2.303 is a factor for converting the natural logarithm to base-10 logarithm, $V_{\text {filter }}$ is the volume of the filtered water $\left(\mathrm{m}^{3}\right)$ and $A_{\mathrm{c}}$ is the clearance area of the filter $\left(\mathrm{m}^{2}\right)$. The clearance area is defined as the area on the filter which is actively used during the filtration. As pigment bleaching with sodium hypochloride may affect the absorption of un-pigmented organic matter in the sample (Ferrari and Tassan, 1999), the determined $a_{\mathrm{ph}}(\lambda)$ can include also some phaeopigments associated with particles other than living phytoplankton. Chlorophyllspecific phytoplankton absorption coefficient $a_{\text {ph }}^{*}(\lambda)$ was obtained by dividing $a_{\mathrm{ph}}(\lambda)$ by the $T C h l$ concentration.

Aliquots for phytoplankton counts $(250 \mathrm{ml}$, Lugol preserved) were analysed with inverted microscope (Ceti Versus, Belgium) under 100x and 400x magnification by using the Utermöhl (1958) technique. The biovolumes of each taxon were estimated by assuming the shape of the species to the closest geometric form (Wetzel and Likens, 1991), after which the biomass (wet weight) was calculated.

For determining the regression formulas and other statistical characteristics the Microsoft's Excel statistical analysis tool 'Data analysis' was used.

\section{RESULTS}

\section{Variation of phytoplankton biomass and species composition}

Seasonal dynamics of phytoplankton composition and biomass (BM) were estimated annually only for the years 2011-2013. Spring phytoplankton BM of Lake Peipsi and Lake Vorrtsjärv was generally dominated by diatoms (Tab. 3). The exception was Lake Peipsi in 2011, when crypto- and chrysophytes were most abundant in biomass. This could be explained by the fact that in 2011 only the northern moderately eutrophic basin of Lake Peipsi was visited, while in 2012-2013 samples were taken also in southern more eutrophic regions. In Lake Harku cyanobacteria dominated in vernal phytoplankton biomass while diatoms were also rather abundant (40\% of BM) in May of all the years.

During summer the share of cyanobacteria in the phytoplankton biomass of all lakes increased reaching average values of $60 \%, 65 \%$ and $71 \%$ in June, July and

Tab. 3. Seasonal ranges of phytoplankton biomass (wet weight, $\mathrm{g} \mathrm{m}^{-3}$ ) in studied turbid Estonian lakes.

\begin{tabular}{lccccccc} 
& \multicolumn{2}{c}{ Lake } & Diatoms & & \multicolumn{3}{c}{ Cyanobacteria } \\
& May & July & Sept & May & \multicolumn{2}{c}{ July } & Sept \\
Peipsi & $0.05-1.13$ & $0.9-5.1$ & $0.4-3.4$ & $0.05-0.4$ & $2.9-13.3$ & $3.2-9.5$ \\
Võrtsjärv & $2.5-11.0$ & $2.8-8.6$ & $3.4-7.7$ & $1.2-3.7$ & $12.5-33.5$ & $6.2-20.7$ \\
\hline Harku & $1.0-4.6$ & 1.28 & $2.4-4.9$ & $1.5-8.1$ & 50.6 & $33.3-89.5$ \\
\hline
\end{tabular}


August, respectively, and remained high until in autumn (53-89\% in September and early October). The proportion of diatoms in summer and autumn ranged $2-60 \%$ and $2-34 \%$, respectively. Chlorophytes formed less than $22 \%$ of phytoplankton biomass during the whole growing season.

The abundance of phytoplankton species in studied lakes changed from chryso- and cryptophytes dominance in May towards cyanobacteria prevalence during summer and autumn (Fig. 1). The most important species of cyanobacteria were Planktolyngbya limnetica in 2011 and Limnothrix redekei and L. planktonica in the subsequent years (2012-2013). Chlorophytes developed from late spring to early autumn and their abundance in lakes varied from 75 cells mL ${ }^{-1}$ (May) to 61050 cells $\mathrm{mL}^{-1}$ (September).

In Lake Harku Scenedesmus spp. was exceptionally abundant. Diatoms abundance peaked in July 2013, when the density of Asterionella formosa in Lake Peipsi rose up to 2454 cells $\mathrm{mL}^{-1}$. However, generally diatoms constituted less than $13 \%$ of total plankton abundance in all studied lakes. Euglenophytes, dinophytes and xantophytes had very little contribution and no evident seasonal variation.

\section{Variability of chlorophyll-specific phytoplankton absorption}

Differences in phytoplankton absorption are related to species composition, pigment content and age of cells, availability of nutrients and light. The spectrum of $a_{\mathrm{ph}}^{*}$ has two maxima, in blue and red region. Our study showed that the variability of $a_{\mathrm{ph}}^{*}$ was greatest in the blue band with values ranging from 0.012 to $0.053 \mathrm{~m}^{2} \mathrm{mg}^{-1}$ at 440 $\mathrm{nm}$. In the red region $(676 \mathrm{~nm}) a_{\mathrm{ph}}^{*}$ ranged between 0.007 and $0.037 \mathrm{~m}^{2} \mathrm{mg}^{-1}$ (Fig. 2).

The spectra had also the shoulders at 420, 490 and
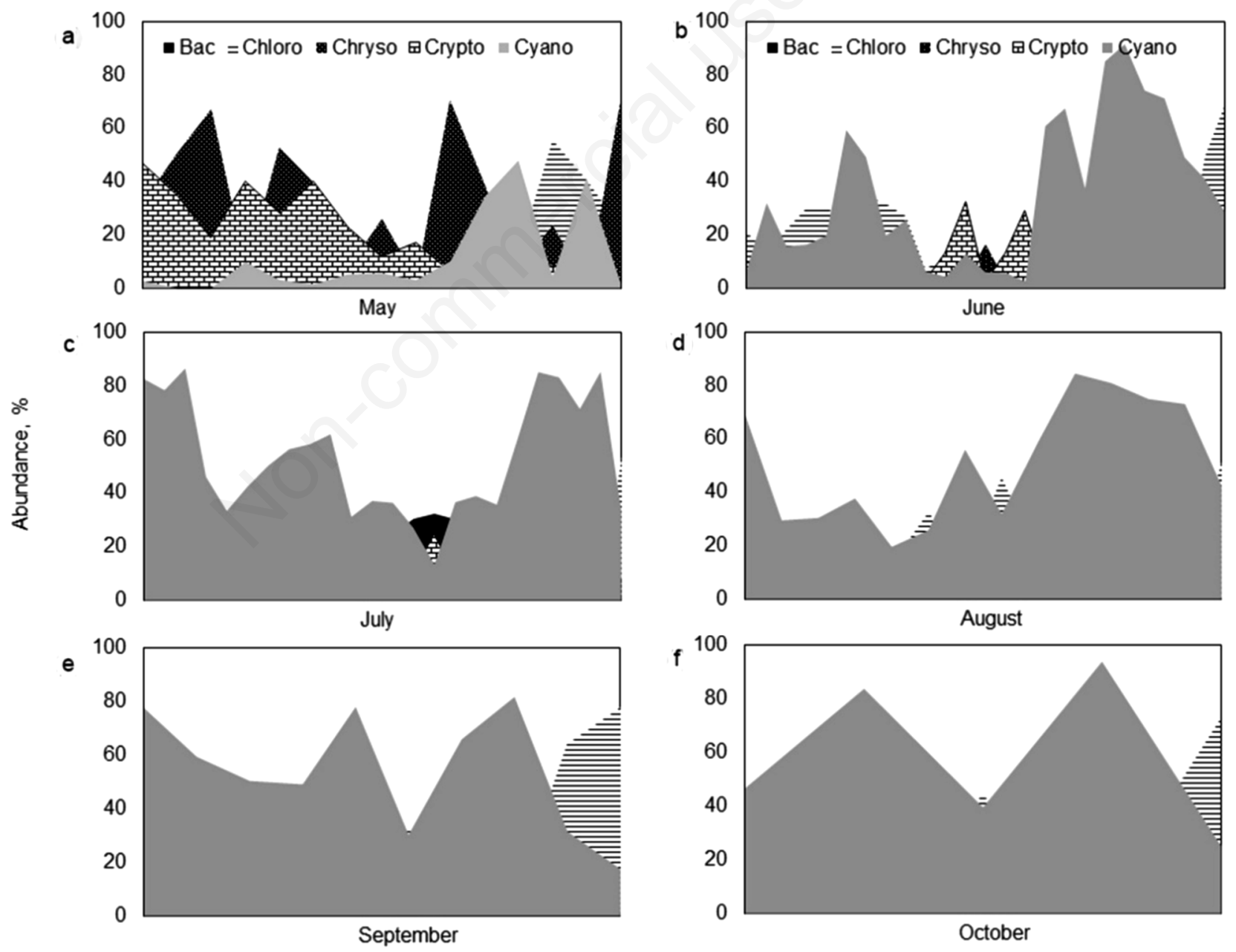

Fig. 1. Dynamics of phytoplankton communities in productive Estonian lakes described by percentages of abundance of major taxonomic assemblages (altogether 81 analyses in 2011-2013). Bac, Bacillariophyta; Chloro, Chlorophyta; Chryso, Chrysophyta; Crypto, Cryptophyta; Cyano, Cyanobacteria. 
$630 \mathrm{~nm}$, associated with accessory pigments (respectively phaeophytins, carotenoids and phycocyanin). The blue to red ratio of $a_{\mathrm{ph}}^{*}(\lambda)$ can be used as an indicator of phytoplankton size, with higher values (e.g., $a_{\mathrm{ph}}^{*}(440) / a_{\mathrm{ph}}^{*}(676)$ $>2.5$ ) known to be associated with the dominance of small-sized populations (Stramski and Morel, 1990). This ratio in turbid productive Estonian lakes varied from 2.9 to 1.1 , demonstrating approximately a 3 -fold decrease when $T C h l$ increased from 2.7 to $315.4 \mathrm{mg} \mathrm{m}^{-3}$.

Several authors (Yentsch and Phinney, 1989; Bricaud et al., 1995, 2004; Ciotti et al., 2002; Babin et al., 2003; Stæhr et al., 2004) found that $a_{\mathrm{ph}}^{*}(\lambda)$ decreases with increasing total chlorophyll concentration and that was also demonstrated in three turbid Estonian lakes (Fig. 3). The greater dispersion of $a_{\mathrm{ph}}^{*}(440)$ compared to $a_{\mathrm{ph}}^{*}(675)$ is explained by the fact that in blue region the package effect as well cellular pigment content and composition have combined influence on $a_{\text {ph }}{ }^{*}$ while in the red band only the package effect is influential (Bricaud et al., 1995, 2004; Lohrenz et al., 2003; Stæhr et al., 2004).

\section{Parameterization of chlorophyll-specific phytoplankton absorption}

To parameterize phytoplankton absorption in the biooptical models, coefficients $A(\lambda)$ and $B(\lambda)$ in eq. 1 were calculated from measured $a_{\mathrm{ph}}^{*}(\lambda)$ spectra. The values of these parameters were tabulated with a $2 \mathrm{~nm}$ step over the range 400-700 nm (Tab. 4). Several studies (Bricaud et al., 1995; Strömbeck, 2001; Stæhr and Markager, 2004; Ficek et al., 2012; Yoshimura et al., 2012; Ylöstalo et al., 2014) have parametrized chlorophyll-specific phytoplankton absorption as power function of TChl. Spectra of the corresponding $A$ and $B$ coefficients (together with our results) are shown in Fig. 4.

In ocean, estuarine and coastal waters coefficient $A(\lambda)$ showed a maximum near $440 \mathrm{~nm}$ (Bricaud et al., 1995; Stæhr and Markager, 2004), whereas in turbid productive Estonian lakes it was shifted towards shorter wavelengths (Fig. 4). Such phenomenon indicates a presence of phaeopigments with a peak around $420 \mathrm{~nm}$. In our lakes the contribution by phaeophytin-a varied between 0.5 and $94 \%$ (with an average 16.7\%) of total chlorophyll concentration. Additionally, we demonstrated a spectral shoulder around $615-645 \mathrm{~nm}$, which is a typical feature of cyanobacteria - characteristic to their phycocyanin pigment (Jeffrey and Vesk, 1997; Simis et al., 2005). In our study the coefficient $B(\lambda)$ had the highest values in the 600-660 $\mathrm{nm}$ region and the lowest in the green part of the spectrum, where $a_{\text {ph }}^{*}$ was not correlated with total chlorophyll concentration (Fig. 4). At minimum $a_{\text {ph }}^{*}$, values of $B$ became unstable and low and even negative in the 476-534 nm region. In Lake Mälaren in Sweden a similar tendency was observed between $580 \mathrm{~nm}$ and $635 \mathrm{~nm}$ (Strömbeck and Pierson, 2001).
To describe $A(\lambda)$ and $B(\lambda)$ coefficients for rather different spring and summer phytoplankton assemblages (Fig. 1 and Tab. 3) we analysed separately two datasets: 20 cases in May for spring and 70 cases in July for summer. In May the values of $A$ at $400-440 \mathrm{~nm}$ were lower than those in

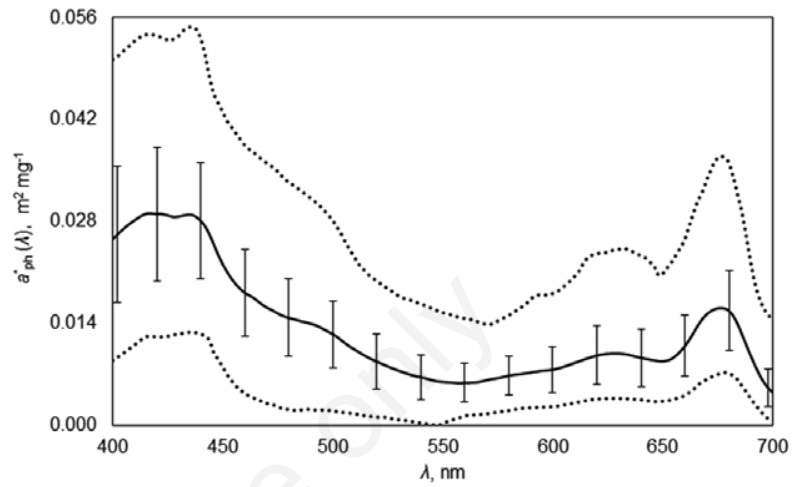

Fig. 2. Variability of chlorophyll-specific phytoplankton absorption coefficient $\left[a_{\mathrm{ph}}^{*}(\lambda)\right]$ measured in three productive Estonian lakes: minimum and maximum spectra (dotted), mean with standard deviations (solid).
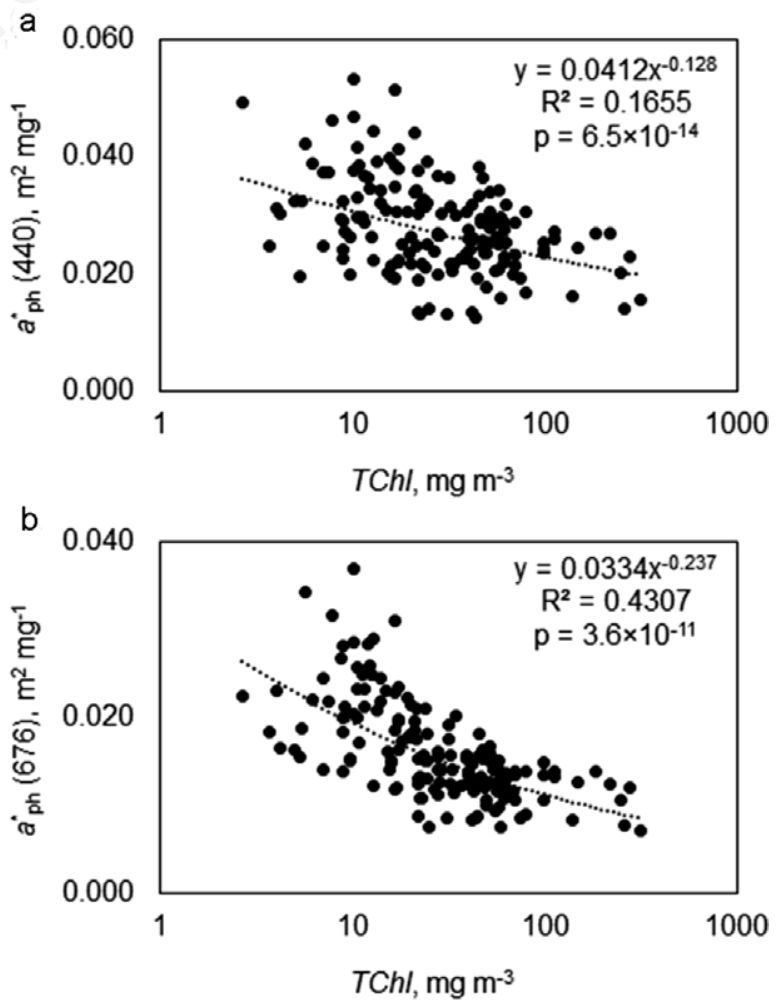

Fig. 3. Dependence of chlorophyll-specific phytoplankton absorption coefficient $a_{\mathrm{ph}}^{*}(\lambda)$ on total chlorophyll concentrations (TChl, chlorophyll- $a+$ phaeopigment- $a$ ) in turbid productive Estonian lakes: (a) at $440 \mathrm{~nm}$ and (b) at $676 \mathrm{~nm}$. 
July, indicating higher package effect and can be explained by the dominance of large cells in vernal phytoplankton. In summer small-celled cyanobacteria dominated, which harvest light with much lower efficiency in the red part of the spectrum the (absorption peak around $630 \mathrm{~nm}$ ). The parameter $B(\lambda)$ also showed a large discrepancy between May and July, reflecting different pigment composition in vernal and summertime phytoplankton assemblages. The spectra of $a_{\mathrm{ph}}^{*}(\lambda)$ in May, July and during the whole summer, measured in situ and calculated using of $A(\lambda)$ and $B(\lambda)$

Tab. 4. Spectral values of the numerical coefficients $A(\lambda)$ and $B(\lambda)$ for the parameterization of chlorophyll-specific phytoplankton absorption coefficient as a function of $T C h l$ in studied turbid Estonian lakes. The values of $R^{2}$ calculated are from power regression. $\mathrm{N}=155$ is the number of water samples use for parameterization.

\begin{tabular}{|c|c|c|c|c|c|c|c|}
\hline$\lambda(\mathrm{nm})$ & $\mathbf{A}$ & B & $R^{2}$ & $\lambda(\mathrm{nm})$ & $\mathbf{A}$ & B & $R^{2}$ \\
\hline 400 & 0.0483 & 0.2114 & 0.2889 & 488 & 0.0122 & -0.0231 & 0.0026 \\
\hline 402 & 0.0498 & 0.2127 & 0.3023 & 490 & 0.0121 & -0.0216 & 0.0022 \\
\hline 404 & 0.0506 & 0.2105 & 0.3055 & 492 & 0.0119 & -0.0201 & 0.0021 \\
\hline 406 & 0.0516 & 0.2104 & 0.3171 & 494 & 0.0117 & -0.0198 & 0.0020 \\
\hline 408 & 0.0526 & 0.2101 & 0.3244 & 496 & 0.0114 & -0.0175 & 0.0020 \\
\hline 410 & 0.0531 & 0.2079 & 0.3232 & 498 & 0.0113 & -0.0151 & 0.0012 \\
\hline 412 & 0.0534 & 0.2054 & 0.3210 & 500 & 0.0112 & -0.0137 & 0.0005 \\
\hline 414 & 0.0537 & 0.2025 & 0.3188 & 502 & 0.0109 & -0.0123 & 0.0005 \\
\hline 416 & 0.0534 & 0.1988 & 0.3150 & 504 & 0.0103 & -0.0108 & 0.0009 \\
\hline 418 & 0.0523 & 0.1950 & 0.3041 & 506 & 0.0098 & -0.0121 & 0.0012 \\
\hline 420 & 0.0516 & 0.1912 & 0.2988 & 508 & 0.0094 & -0.0133 & 0.0011 \\
\hline 422 & 0.0514 & 0.1873 & 0.2949 & 510 & 0.0091 & -0.0146 & 0.0010 \\
\hline 424 & 0.0503 & 0.1819 & 0.2842 & 512 & 0.0086 & -0.0176 & 0.0013 \\
\hline 426 & 0.0486 & 0.1724 & 0.2631 & 514 & 0.0082 & -0.0207 & 0.0017 \\
\hline 428 & 0.0472 & 0.1645 & 0.2488 & 516 & 0.0078 & -0.0232 & 0.0020 \\
\hline 430 & 0.0467 & 0.1602 & 0.2410 & 518 & 0.0075 & -0.0247 & 0.0023 \\
\hline 432 & 0.0462 & 0.1554 & 0.2316 & 520 & 0.0072 & -0.0266 & 0.0025 \\
\hline 434 & 0.0454 & 0.1495 & 0.2170 & 522 & 0.0069 & -0.0282 & 0.0026 \\
\hline 436 & 0.0446 & 0.1435 & 0.2024 & 524 & 0.0066 & -0.0262 & 0.0025 \\
\hline 438 & 0.0431 & 0.1361 & 0.1847 & 526 & 0.0064 & -0.0243 & 0.0022 \\
\hline 440 & 0.0412 & 0.1280 & 0.1655 & 528 & 0.0064 & -0.0206 & 0.0013 \\
\hline 442 & 0.0389 & 0.1193 & 0.1455 & 530 & 0.0062 & -0.0160 & 0.0010 \\
\hline 444 & 0.0363 & 0.1116 & 0.1260 & 532 & 0.0061 & -0.0089 & 0.0004 \\
\hline 446 & 0.0337 & 0.1060 & 0.1102 & 534 & 0.0060 & -0.0018 & 0.0003 \\
\hline 448 & 0.0311 & 0.0999 & 0.0949 & 536 & 0.0058 & 0.0053 & 0.0001 \\
\hline 450 & 0.0287 & 0.0929 & 0.0785 & 538 & 0.0061 & 0.0165 & 0.0004 \\
\hline 452 & 0.0264 & 0.0837 & 0.0604 & 540 & 0.0063 & 0.0278 & 0.0022 \\
\hline 454 & 0.0246 & 0.0762 & 0.0471 & 542 & 0.0063 & 0.0343 & 0.0030 \\
\hline 456 & 0.0229 & 0.0680 & 0.0354 & 544 & 0.0060 & 0.0329 & 0.0018 \\
\hline 458 & 0.0217 & 0.0612 & 0.0274 & 546 & 0.0059 & 0.0314 & 0.0022 \\
\hline 460 & 0.0204 & 0.0553 & 0.0188 & 548 & 0.0062 & 0.0310 & 0.0019 \\
\hline 462 & 0.0198 & 0.0495 & 0.0168 & 550 & 0.0064 & 0.0626 & 0.0108 \\
\hline 464 & 0.0193 & 0.0463 & 0.0149 & 552 & 0.0069 & 0.0830 & 0.0208 \\
\hline 466 & 0.0181 & 0.0378 & 0.0092 & 554 & 0.0072 & 0.0986 & 0.0297 \\
\hline 468 & 0.0169 & 0.0263 & 0.0043 & 556 & 0.0075 & 0.1077 & 0.0352 \\
\hline 470 & 0.0162 & 0.0194 & 0.0023 & 558 & 0.0079 & 0.1271 & 0.0560 \\
\hline 472 & 0.0157 & 0.0159 & 0.0015 & 560 & 0.0083 & 0.1395 & 0.0741 \\
\hline 474 & 0.0149 & 0.0081 & 0.0004 & 562 & 0.0086 & 0.1482 & 0.0888 \\
\hline 476 & 0.0141 & -0.0015 & 0.0000 & 564 & 0.0090 & 0.1598 & 0.1097 \\
\hline 478 & 0.0135 & -0.0092 & 0.0005 & 566 & 0.0097 & 0.1715 & 0.1201 \\
\hline 480 & 0.0130 & -0.0144 & 0.0011 & 568 & 0.0103 & 0.1833 & 0.1556 \\
\hline 482 & 0.0127 & -0.0189 & 0.0018 & 570 & 0.0109 & 0.1967 & 0.1886 \\
\hline 484 & 0.0124 & -0.0216 & 0.0024 & 572 & 0.0115 & 0.2049 & 0.2126 \\
\hline 486 & 0.0123 & -0.0224 & 0.0031 & 574 & 0.0119 & 0.2108 & 0.2336 \\
\hline
\end{tabular}


values from Tab. 4, show rather good correspondence in many cases while also discrepancies in the blue and red regions were observed (Fig. 5). Underestimation of $a_{\mathrm{ph}}^{*}$ in the blue region was generally accompanied by an overestimation of $a_{\mathrm{ph}}^{*}$ in the red region and vice versa. The mismatch between measured and modelled $a_{\text {ph }}^{*}(\lambda)$ values appeared mainly for low and extremely total high chlorophyll concentration, e.g., a large discrepancy from measured and modelled $a_{\mathrm{ph}}^{*}$ spectra occurred in May, when $T C h l$ in Lake Peipsi was below $8 \mathrm{mg} \mathrm{m}^{-3}$ (Fig. 5a).

Since our database included only $13 \%$ of cases with $T C h l<10 \mathrm{mgm}^{-3}$, the seasonal models for such low TChl values cannot be fully reliable. In Lake Harku where vernal $T C h l$ reached up $113 \mathrm{mg} \mathrm{m}^{-3}$, the parameterization for May gave rather good results (Fig. 5e) while the applicability of July model for summer months depended on the prevalence of cyanobacteria. A further study could help to decide whether the best option is to elaborate two separate parame- terization for the blue and red regions of spectra or to use a model which takes into account also the variability of phytoplankton species composition. Total chlorophyll values above $150 \mathrm{mg} \mathrm{m}^{-3}$ were observed only in Lake Harku and in this TChl region both our seasonal models failed (Fig. 5f). As we did not find remarkable decrease of $a_{\mathrm{ph}}^{*}(\lambda)$ with increase at $T C h l>80 \mathrm{mg} \mathrm{m}^{-3}$ (Fig. 3), this explains the mismatch between measured and modelled $a_{\mathrm{ph}}^{*}(\lambda)$ spectra for $T C h l$ values above $100 \mathrm{mgm}^{-3}$ in Lake Harku.

Analysing the correspondence of measured and modelled $a_{\mathrm{ph}}^{*}$ values in blue $(442 \mathrm{~nm})$ and red $(676 \mathrm{~nm})$ wavelengths. We found that at $442 \mathrm{~nm}$ the determination coefficients $\left(\mathrm{R}^{2}\right)$ were remarkably lower than those at $676 \mathrm{~nm}$, except in May, when $\mathrm{R}^{2}(442)$ was 0.548 and $\mathrm{R}^{2}(676)$ was 0.325 (Fig. 6 and Tab. 5). The highest $\mathrm{R}^{2}$ value (0.649) appeared in July at $676 \mathrm{~nm}$. Generally $\mathrm{R}^{2}$ values for May and July separately exceeded those calculated for the whole database, expressing the impact of

Tab. 4. Continued from previous page.

\begin{tabular}{|c|c|c|c|c|c|c|c|}
\hline$\lambda(\mathrm{nm})$ & A & B & $R^{2}$ & $\lambda(\mathrm{nm})$ & A & B & $R^{2}$ \\
\hline 576 & 0.0124 & 0.2182 & 0.2580 & 640 & 0.0228 & 0.3007 & 0.4522 \\
\hline 578 & 0.0131 & 0.2282 & 0.2856 & 642 & 0.0227 & 0.3010 & 0.4535 \\
\hline 580 & 0.0137 & 0.2352 & 0.3097 & 644 & 0.0223 & 0.3009 & 0.4533 \\
\hline 582 & 0.0142 & 0.2421 & 0.3325 & 646 & 0.0220 & 0.2994 & 0.4501 \\
\hline 584 & 0.0147 & 0.2491 & 0.3434 & 648 & 0.0215 & 0.2953 & 0.4477 \\
\hline 586 & 0.0152 & 0.2552 & 0.3605 & 650 & 0.0211 & 0.2909 & 0.4445 \\
\hline 588 & 0.0157 & 0.2622 & 0.3758 & 652 & 0.0213 & 0.2890 & 0.4488 \\
\hline 590 & 0.0162 & 0.2677 & 0.3828 & 654 & 0.0218 & 0.2870 & 0.4537 \\
\hline 592 & 0.0168 & 0.2749 & 0.3923 & 656 & 0.0229 & 0.2868 & 0.4641 \\
\hline 594 & 0.0172 & 0.2795 & 0.3977 & 658 & 0.0242 & 0.2847 & 0.4708 \\
\hline 596 & 0.0176 & 0.2835 & 0.4059 & 660 & 0.0259 & 0.2837 & 0.4772 \\
\hline 598 & 0.0178 & 0.2856 & 0.4089 & 662 & 0.0278 & 0.2812 & 0.4808 \\
\hline 600 & 0.0181 & 0.2878 & 0.4124 & 664 & 0.0295 & 0.2746 & 0.4778 \\
\hline 602 & 0.0187 & 0.2899 & 0.4169 & 666 & 0.0311 & 0.2676 & 0.4670 \\
\hline 604 & 0.0191 & 0.2920 & 0.4187 & 668 & 0.0325 & 0.2606 & 0.4640 \\
\hline 606 & 0.0197 & 0.2939 & 0.4244 & 670 & 0.0334 & 0.2550 & 0.4578 \\
\hline 608 & 0.0203 & 0.2943 & 0.4256 & 672 & 0.0339 & 0.2488 & 0.4521 \\
\hline 610 & 0.0208 & 0.2952 & 0.4291 & 674 & 0.0337 & 0.2426 & 0.4371 \\
\hline 612 & 0.0214 & 0.2949 & 0.4295 & 676 & 0.0334 & 0.2374 & 0.4307 \\
\hline 614 & 0.0218 & 0.2941 & 0.4307 & 678 & 0.0329 & 0.2337 & 0.4246 \\
\hline 616 & 0.0223 & 0.2934 & 0.4334 & 680 & 0.0320 & 0.2313 & 0.4202 \\
\hline 618 & 0.0228 & 0.2928 & 0.4344 & 682 & 0.0302 & 0.2284 & 0.4125 \\
\hline 620 & 0.0233 & 0.2939 & 0.4382 & 684 & 0.0280 & 0.2295 & 0.4146 \\
\hline 622 & 0.0236 & 0.2946 & 0.4400 & 686 & 0.0255 & 0.2356 & 0.4222 \\
\hline 624 & 0.0240 & 0.2957 & 0.4437 & 688 & 0.0231 & 0.2454 & 0.4313 \\
\hline 626 & 0.0241 & 0.2960 & 0.4460 & 690 & 0.0208 & 0.2580 & 0.4399 \\
\hline 628 & 0.0242 & 0.2971 & 0.4494 & 692 & 0.0183 & 0.2703 & 0.4365 \\
\hline 630 & 0.0244 & 0.2993 & 0.4521 & 694 & 0.0166 & 0.2932 & 0.4341 \\
\hline 632 & 0.0243 & 0.2998 & 0.4538 & 696 & 0.0157 & 0.3325 & 0.4422 \\
\hline 634 & 0.0240 & 0.2998 & 0.4536 & 698 & 0.0155 & 0.3770 & 0.4423 \\
\hline 636 & 0.0235 & 0.3001 & 0.4496 & 700 & 0.0152 & 0.4183 & 0.4280 \\
\hline 638 & 0.0230 & 0.3004 & 0.4495 & & & & \\
\hline
\end{tabular}


phytoplankton composition in different seasons. Phytoplankton in the analysed turbid lakes changed from chrysoand cryptophytes dominance in May to a predominance of small-celled cyanobacteria during whole summer. In July the determination coefficient of our $a_{\mathrm{ph}}^{*}$ model was much higher $\left(\mathrm{R}^{2}=0.65\right)$ in the red wavelength $(676 \mathrm{~nm})$ than in blue region (at $442 \mathrm{~nm} \mathrm{R}^{2}=0.25$ ) where $a_{\text {ph }}^{*}$ values are affected by both pigment composition and packaging, but their relative importance is difficult to resolve. In our whole dataset the correspondence of $a_{\mathrm{ph}}^{*}$ (meas) $v s a_{\mathrm{ph}}^{*}$ (modelled) at $676 \mathrm{~nm}$ was a bit weaker $\left(\mathrm{R}^{2}=0.49\right)$ because of the larger variety of algal groups cell sizes. Chlorophyll- $a$ content of cells varies between different phytoplankton groups and cyanobacteria, which prevailed in our study lakes in July and August, have more accessory pigments and less Chl-a per unit biovolume than other algae, e.g., chlorophytes (Reynolds, 2006).

\section{DISCUSSION}

\section{Chlorophyll-specific phytoplankton absorption in ocean, coastal and lake waters}

In different water bodies chlorophyll-specific phytoplankton absorption coefficient values vary in large scale. In blue spectral region Bricaud et al. (1995) derived a range of $a_{\mathrm{ph}}^{*}(440)$ between 0.01 and $0.18 \mathrm{~m}^{2} \mathrm{mg}^{-1}$ for ocean waters, whilst Stæhr and Markager (2004) extended this range to $0.015-0.194 \mathrm{~m}^{2} \mathrm{mg}^{-1}$ for estuarine

Tab. 5. Statistical analysis of the correspondence of the measured (x) and modelled (y) $a_{\mathrm{ph}}^{*}$ at $442 \mathrm{~nm}$ and $676 \mathrm{~nm}$.

\begin{tabular}{|c|c|c|c|c|c|c|}
\hline Data & $\mathbf{R}^{2}$ & SE & $P$ & MIRE (\%) & $\mathbf{N}$ & Regression \\
\hline \multicolumn{7}{|l|}{$442 \mathrm{~nm}$} \\
\hline All & 0.195 & 0.0026 & $3 \cdot 10^{-8}$ & 1.45 & 155 & $y=0.022+0.182 x$ \\
\hline May & 0.548 & 0.0026 & 0.0003 & 2.22 & 20 & $y=0.015+0.442 x$ \\
\hline July & 0.254 & 0.0035 & $3 \cdot 10^{-5}$ & 3.76 & 70 & $y=0.020+0.247 x$ \\
\hline \multicolumn{7}{|l|}{$676 \mathrm{~nm}$} \\
\hline All & 0.495 & 0.0025 & $1 \cdot 10^{-22}$ & 3.23 & 155 & $y=0.087+0.459 x$ \\
\hline May & 0.325 & 0.0013 & 0.011 & 2.25 & 20 & $y=0.011+0.417 x$ \\
\hline July & 0.649 & 0.0031 & $3 \cdot 10^{-15}$ & 4.63 & 70 & $y=0.007+0.621 x$ \\
\hline
\end{tabular}

$M R E$, mean relative error.
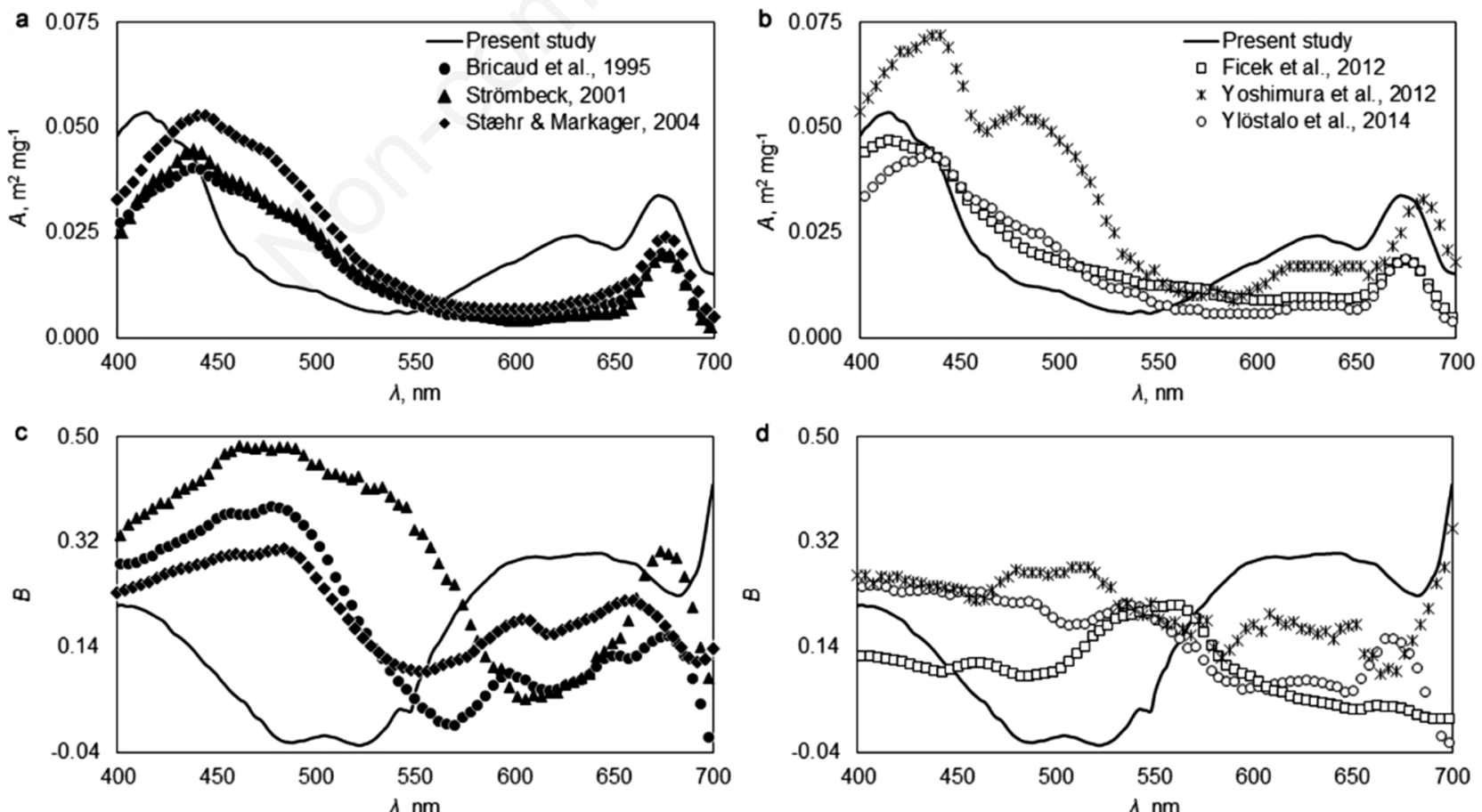

Fig. 4. Parameters $A$ and $B$ for modelling chlorophyll-specific phytoplankton absorption coefficient in different water bodies: (left column) for ocean, coastal and archipelago waters together with three clear Swedish lakes and (right column) for productive lakes. 
and coastal waters. In lakes in southern Finland $a_{\mathrm{ph}}^{*}(440)$ varied from 0.012 to $0.038 \mathrm{~m}^{2} \mathrm{mg}^{-1}$ (Ylöstalo et al., 2014) and in lakes Erken and Kasumigaura from 0.009 to 0.058 $\mathrm{m}^{2} \mathrm{mg}^{-1}$ (Strömbeck, 2001; Yoshimura et al., 2012). In the red spectral region the reported values in ocean, coastal waters and lakes have been quite similar (0.004$0.04 \mathrm{~m}^{2} \mathrm{mg}^{-1}$ ) compared to those in blue region (Dekker, 1993; Le et al., 2009; Yoshimura et al., 2012; Perkins et al., 2014; references in Ylöstalo et al., 2014). In three turbid productive Estonian lakes $a_{\mathrm{ph}}^{*}$ values $0.012-0.053 \mathrm{~m}^{2}$ $\mathrm{mg}^{-1}$ at $440 \mathrm{~nm}$ and $0.007-0.037 \mathrm{~m}^{2} \mathrm{mg}^{-1}$ at $676 \mathrm{~nm}$ were in same scale with the earlier studies.

The blue to red absorption ratios in the studied Estonian lakes (mean 1.81) were lower than in Lake Taihu (range 1.08-13.9; Le et al., 2009), but comparable to those in the
Baltic Sea (1.67-2.54; Seppälä et al., 2005) and other inland waters, like boreal lakes in Southern-Finland (1.102.38; Ylöstalo et al., 2014) and three clear-water lakes in Sweden (0.73-3.70; Strömbeck, 2001).

\section{Comparison of parameterizations for ocean, coastal and lake waters}

Several studies (Bricaud et al., 1995; Strömbeck, 2001; Stæhr and Markager, 2004; Ficek et al., 2012; Yoshimura et al., 2012; Ylöstalo et al., 2014) have parameterized chlorophyll-specific phytoplankton absorption as power function of $T C h l$ (Fig. 4).

In general, our parameter $A$ spectrum had similar features with others -presence of two distinctive peaks at the blue and the red wavelengths in visible range,
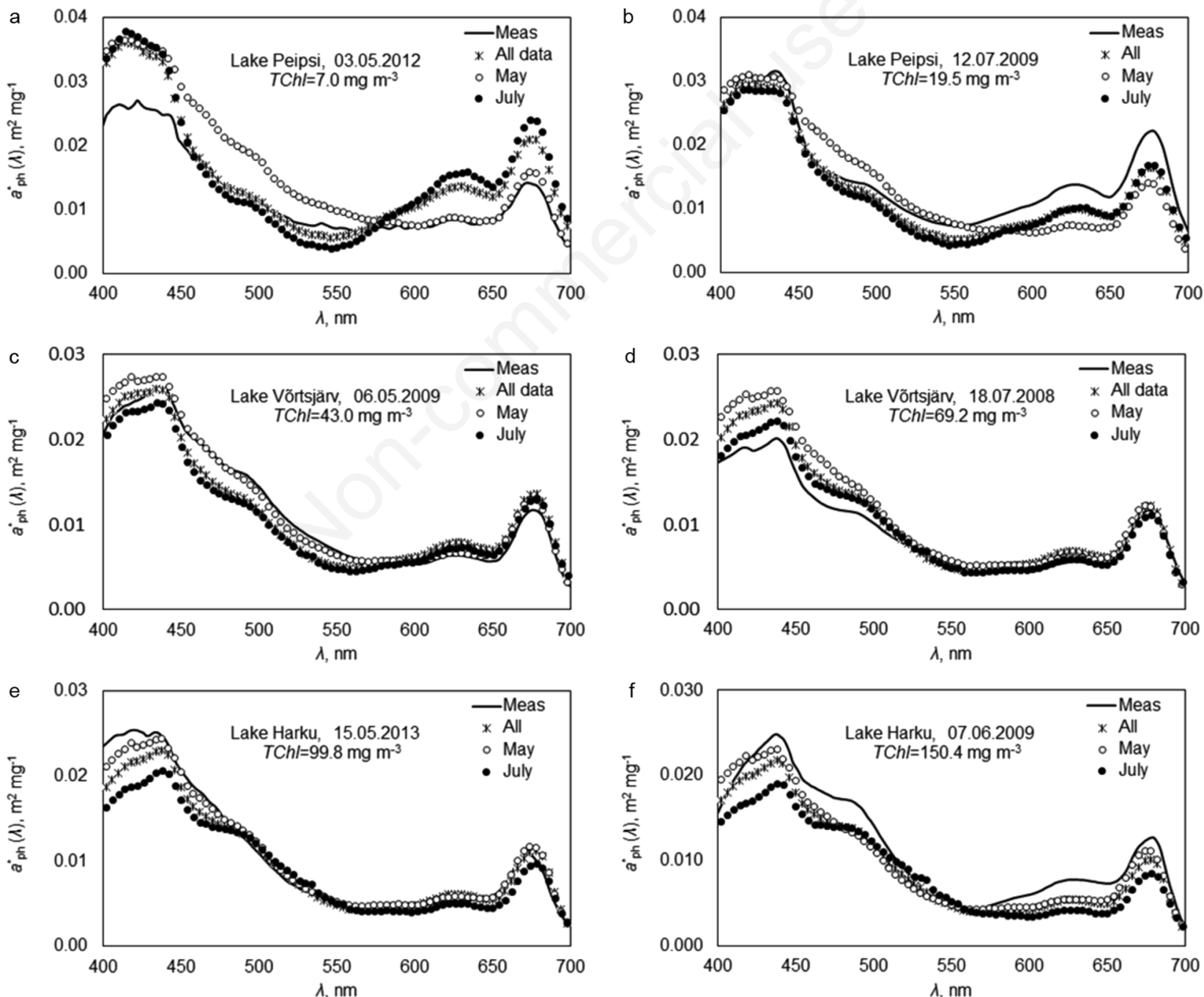

Fig. 5. Chlorophyll-specific phytoplankton absorption coefficient $\left(a_{\mathrm{ph}}^{*}(\lambda)\right)$ in three turbid productive Estonian lakes measured in situ and calculated on the basis of total chlorophyll (TChl) concentrations and $A(\lambda)$ and $B(\lambda)$ values from Tab. 4. 
associated with the absorption of chlorophyll-a. However, few remarkable differences were also noticed. In our study the most pronounced inconsistency occurred around $630 \mathrm{~nm}$, where various cyanobacterial pigments, like phycocyanin, are known to absorb (Simis et al., 2005) and the position of the blue peak of $A$ appeared at $420 \mathrm{~nm}$ (Fig. 4) instead it common occurrence at $440 \mathrm{~nm}$. This shift could be attributed to larger contribution of phaeophytin-a, that is characteristic to eutrophic waters, as its absorption peak is located at a shorter wavelength than that of chlorophyll-a (Bricaud et al., 1995). Such shifts of the peak location have been observed also in cryphytophyte-dominated lakes of southern Finland where peak of coefficient $A(\lambda)$ at $570 \mathrm{~nm}$ was attributed to large contribution of crypto-phycoerythrin pigment (Ylöstalo et al., 2014). In Lake Kasumiguara (Yoshimura et al., 2012) coefficient $A$ had a shoulder between $485 \mathrm{~nm}$ and $505 \mathrm{~nm}$ (Fig. 4b) caused by various carotenoid pigments. The parameter $B(\lambda)$ shows also great differences between sea waters and lakes. The spectral behaviour of $B$ for ocean, coastal and archipelago waters was rather similar (Fig. 4), but the magnitude was somewhat different, resulting from a weaker package effect in brackish archipelago waters (Strömbeck, 2001). The small shoulder around $660 \mathrm{~nm}$ of the $B$ spectra (Bricaud et al., 1995; Stæhr and Markager, 2004) could appear in the presence of Prochlorococcus, species, which have been observed mainly in oligotrophic waters (Partensky et al., 1993).

\section{Influence of the package effect on the parameterization of $\boldsymbol{a}_{\mathrm{ph}}^{*}(\lambda)$}

According to IOCCG (2000), phytoplankton populations found in oligotrophic waters have higher $a_{\mathrm{ph}}^{*}(\lambda)$ values than those in eutrophic waters. The package effect increases when either the cell size or the pigment concentration of the cellular material increases, as a result of depressing phytoplankton absorption at all wavelengths and flattening the $a_{\mathrm{ph}}^{*}$ spectrum (Yentsch and Phinney, 1989; Cleveland, 1995; Bricaud et al., 1995, 2004). Our parameterization predicted approximately 2-time variation of $a_{\mathrm{ph}}^{*}(440)$ when total chlorophyll varied in the range of $5-240 \mathrm{mg} \mathrm{m}^{-3}$ (Fig. 7b). In the range of 580-700 nm the values of $a_{\mathrm{ph}}^{*}$ at $T C h l=5 \mathrm{mg} \mathrm{m}^{-3}$ were much bigger than those at higher TChl (30-240 $\left.\mathrm{mg} \mathrm{m}^{-3}\right)$. It should be considered, however, that our database comprised only samples of total chlorophyll values less than $5 \mathrm{mg} \mathrm{m}^{-3}$ and that could at least partly explain the discrepancy of $a_{\mathrm{ph}}^{*}(\lambda)$ at $T C h l=5 \mathrm{mg} \mathrm{m}^{-3}$ from those at greater $T C h l$ values. For any water type separately the increase of TChl accompanied by the decrease of $a_{\mathrm{ph}}^{*}(\lambda)$, except in the some parts of spectrum, where the change of absorption due to total chlorophyll concentration was very small (Fig. 7 c-j). One should consider that for modelling $a_{\mathrm{ph}}^{*}(\lambda)$ both the varia- tion range of total chlorophyll concentrations and the contribution of different $T C h l$ values are important. For example, in northern Polish lakes (Ficek et al., 2012) the variation range of $T C h l$ was comparable to those in three productive Estonian lakes, whilst the average values of chlorophyll concentrations were rather different, respectively 26.9 and $42.5 \mathrm{mg} \mathrm{m}^{-3}$ and that probably caused also the different results of modelling.

\section{Applicability of the parameterizations of phytoplankton absorption spectra for different aquatic environments}

Comparison of different modelling results indicated their dependence on the physical and chemical conditions in the aquatic environments as well as on the phytoplankton pigment composition, which in lakes are divergent
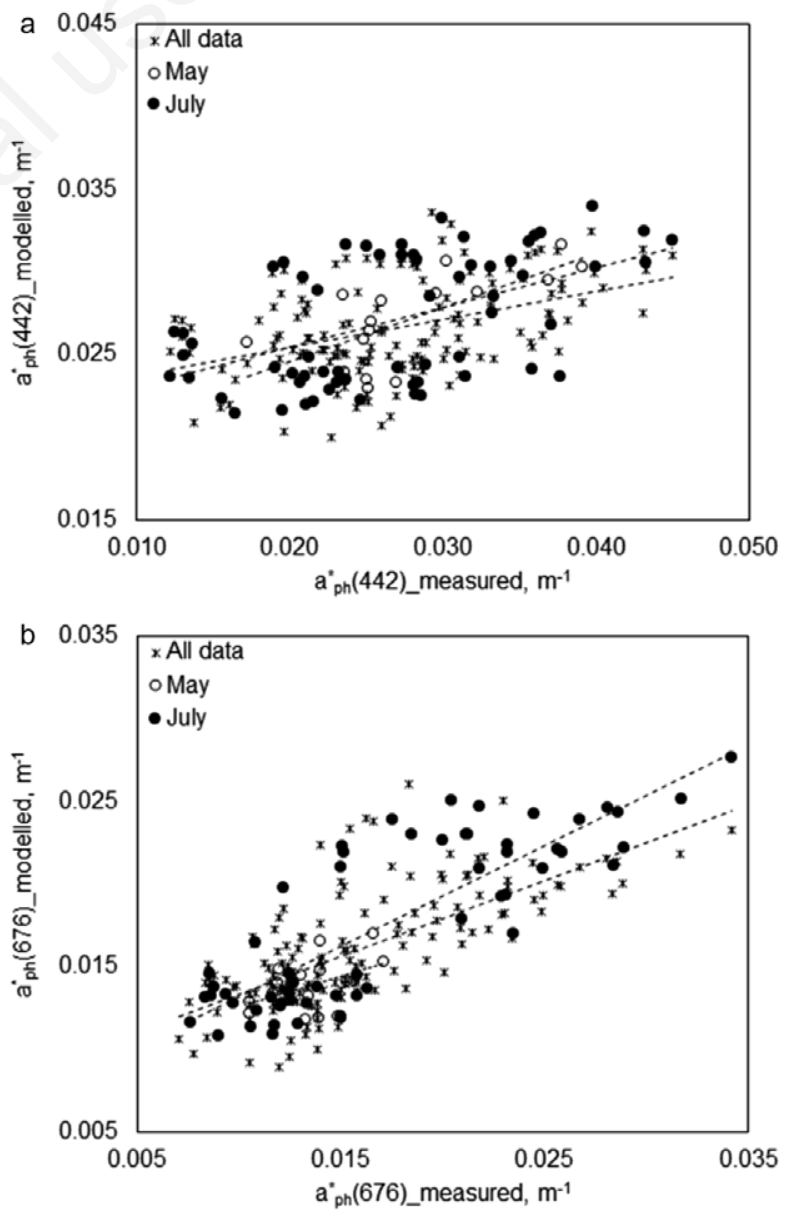

Fig. 6. Modelled $v s$ measured chlorophyll-specific phytoplankton absorption coefficient $\left(a_{\mathrm{ph}}^{*}(\lambda)\right)$ for turbid productive Estonian lakes. Months in the legend are corresponding to the seasonal models used for parameterization of $a_{\mathrm{ph}}^{*}(\lambda)$. The corresponding statistical characteristics are shown in Tab. 5. 
from those in ocean and coastal waters. For instance, we cannot use the results of Bricaud et al. (1995) on eutrophic lakes as their $A(\lambda)$ and $B(\lambda)$ parameterization was limited to the $T C h l$ values up to $25 \mathrm{mg} \mathrm{m}^{-3}$. Outside this upper boundary an abnormal increase of $a_{\mathrm{ph}}{ }_{\mathrm{p}}(\lambda)$ in the spectral region of 500-600 nm was observed (Fig. 8 c,e,g,i). Similarly, the model of the Stæhr and Markager (2004) did not perform well in the conditions of total chlorophyll values above $100 \mathrm{mg} \mathrm{m}^{-3}$. For this parameterization the artificial shoulder was shifted towards shorter wavelengths (Fig. 8 e,g,i). In three relatively clear Swedish lakes together with brackish archipelago waters in Stockholm (Strömbeck, 2001) the spectral behaviour of $a_{\mathrm{ph}}^{*}(\lambda)$ was rather similar to those in ocean and coastal waters (Fig. 8). Consequently, all the three parameterizations mentioned above (Bricaud et al., 1995; Strömbeck, 2001; Stæhr and Markager, 2004) predict much lower chlorophyll-specific phytoplankton absorption than those observed in turbid productive lakes.

The largest discrepancy in parameterizations of lake models was observed for $T C h l$ values below $5 \mathrm{mg} \mathrm{m}^{-3}$ (Fig. 8a), which could be explained by the fact that in these parameterizations the contribution of such a low total chlorophyll concentrations were almost negligible. Additionally, we have to take into account that our databased comprised only four samples of TChl values less than 5 $\mathrm{mg} \mathrm{m}^{-3}$. A good coincidence - especially in the red part of the spectrum - was noticed (almost for all models) in cases, when TChl was around $30 \mathrm{mg} \mathrm{m}^{-3}$ (Fig. 8). For higher total chlorophyll values our parameterization
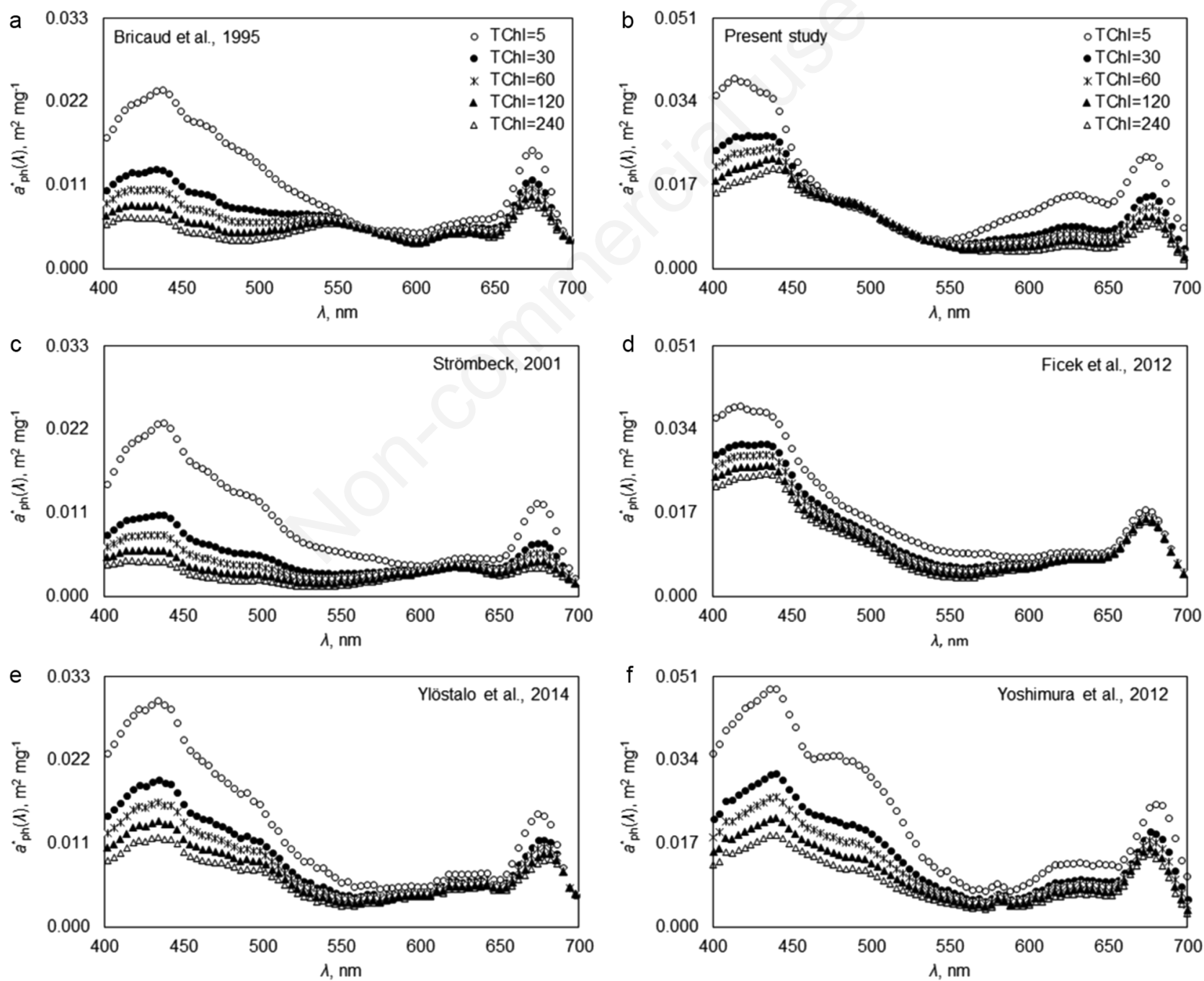

Fig. 7. Spectral distribution of $a_{\mathrm{ph}}^{*}(\lambda)$ for $T C h l$ concentrations between $5 \mathrm{mg} \mathrm{m}^{-3}$ and $240 \mathrm{mg} \mathrm{m}^{-3}$. Left column: for ocean, brackish archipelago and clear inland waters; right column: for productive lakes. 

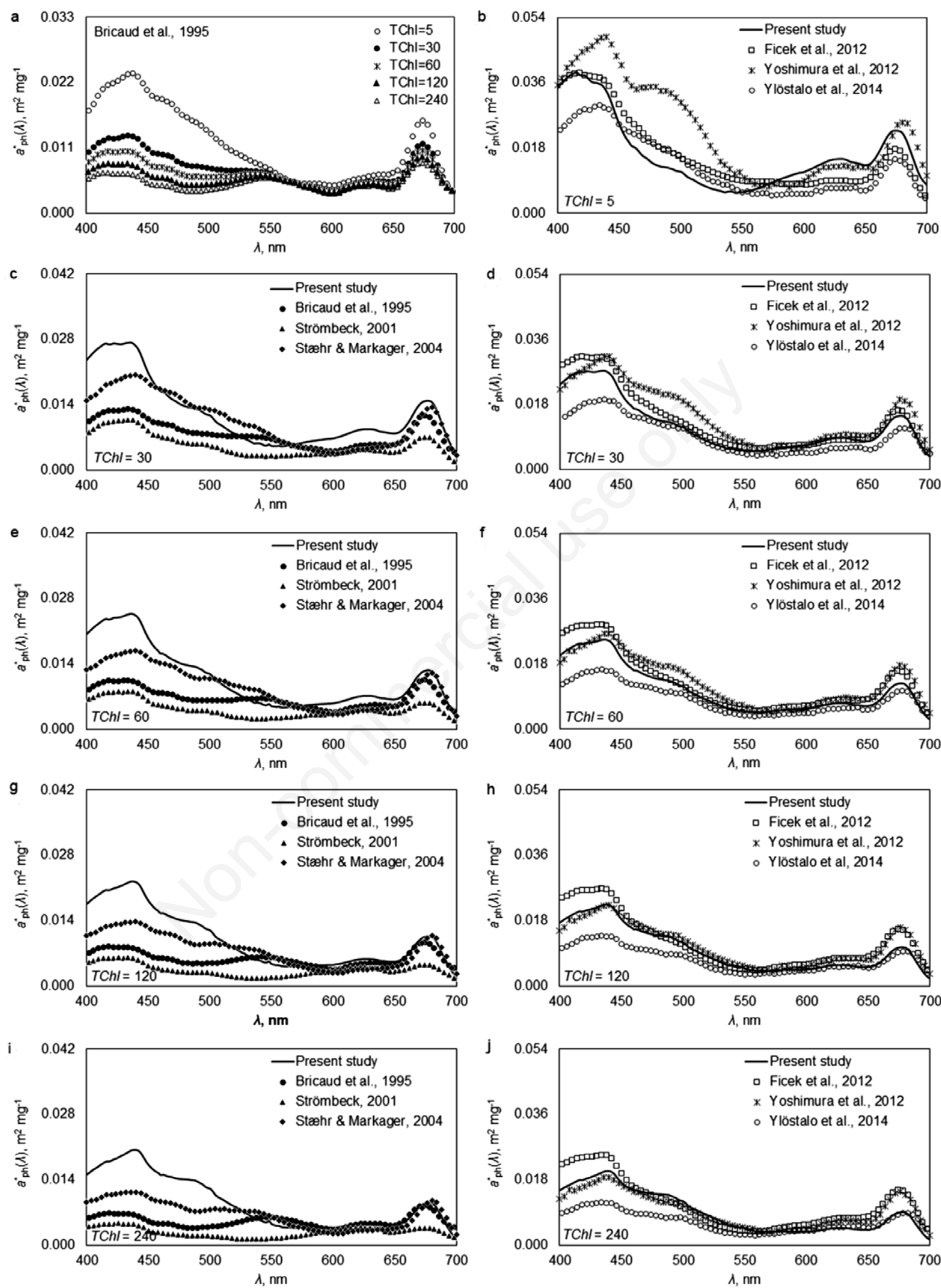

Fig. 8. Chlorophyll-specific phytoplankton absorption spectra for various values of total chlorophyll concentration (from 5 to $240 \mathrm{mg} \mathrm{m}^{-3}$ ), calculated using eq. 1 with the spectral values of parameters $A(\lambda)$ and $B(\lambda)$ recommended by cited authors and modelled in present study. 
had similar features to several studies (Fig. 8f), but in different spectral regions: in the blue absorption band with the results by Yoshimura et al. (2012) and in the red part of spectrum with results by Ylöstalo et al. (2014). The compatibility with Polish lakes (Ficek et al., 2012) was noticed mainly between $490-550 \mathrm{~nm}$. It seems that the improvement of the parameterization of $a_{\mathrm{ph}}^{*}(\lambda)$ spectra for productive and hypertrophic lakes needs a larger dataset, which includes simultaneous measurements of total chlorophyll concentrations, phytoplankton absorption coefficients and - as revealed in the current study - phytoplankton species composition of these inland waters.

In the present study we investigated the chlorophyllspecific phytoplankton absorption coefficients and how to predict these spectra in the case of turbid productive lakes. However, bio-optical models that are used to simulate water reflectance spectra require also the spectra of backscattering coefficient (Gordon et al., 1988). Phytoplankton backscattering coefficient spectra are usually smooth with decrease towards longer wavelengths (Ahn et al., 1992; Kutser, 2004; Vaillancourt et al., 2004; Metsamaa et al., 2006). The exception could be cyanobacteria, which have gas vesicles in their cells that may backscatter light selectively. Note, the published backscattering coefficient spectra for cyanobacteria (Ahn et al., 1992; Kutser, 2004; Metsamaa et al., 2006) do not have high enough spectral resolution in order to determine that with great certainty. Absorption coefficient of CDOM decreases exponentially with increasing wavelength and absorption and backscattering properties of water molecules and mineral particles are spectrally smooth (Kutser et al., 2001). Consequently, in eutrophic lakes the specific absorption coefficient, studied by us, is the most important factor determining the shape of water reflectance spectra. The approach proposed by Bricaud et al. (1995) has been used in semi-analytical reflectance models for nearly two decades (Kutser, 1997; Kutser et al., 2001). However, the results of our study should help to improve the performance of the semi-empirical and radiative transfer models also requiring $a_{\mathrm{ph}}^{*}(\lambda)$ as an input parameter.

\section{CONCLUSIONS}

In the present paper we examined and parameterized a model that allows calculating the chlorophyll-specific phytoplankton absorption coefficient spectra for turbid lakes. This kind of models should be developed and validated for improving remote sensing algorithms, estimation of primary production and retrieval of phytoplankton community structure from optical data. The coefficients $A(\lambda)$ and $B(\lambda)$ of our model differ from those found in sea, coastal waters and other types of lakes. For any water type separately the increase of total chlorophyll concentration accompanied with the decrease of $a_{\mathrm{ph}}^{*}$. Our results showed significant seasonal differences between the model parameters due to diversity of the phytoplankton assemblages. This suggests that season-specific models should be developed and validated. Improving the modelling of chlorophyll-specific phytoplankton absorption spectra for productive and hypertrophic lakes is still pending on the availability of a larger dataset, which includes simultaneous measurements of chlorophyll concentrations, phytoplankton absorption coefficients and phytoplankton species composition of inland waters. Our results implied that total chlorophyll concentration is not a universal predictor of the magnitude of chlorophyll-specific phytoplankton absorption coefficient. The $a_{\text {ph }}^{*}(\lambda)$ models are also likely site and season dependent. Further research is needed for quantifying the role of accessory pigments and other optical constituents as well as the cell size of dominant algal species for considering their influence on the modelling outputs.

\section{ACKNOWLEDGMENTS}

This research was supported by Estonian Science Foundation (grants 7156, 8576, 8654 and 9102), and by Estonian Ministry of Education and Research (institutional research funding project IUT21-2). The authors are grateful to Dr. Tuuli Kauer and Evi Lill for their help with laboratory analyses.

\section{REFERENCES}

Ahn Y-H, Bricaud A, Morel A, 1992. Light backscattering efficiency and related properties of some phytoplankters. DeepSea Res. 39:1835-1855.

Alikas K, Kangro K, Reinart, A, 2010. Detecting cyanobacterial blooms in large North European lakes using the Maximum Chlorophyll Index. Oceanologia 52:237-257.

Allali K, Bricaud A, Claustre H, 1997. Spatial variations in the chlorophyll-specific absorption coefficients of phytoplankton and photosynthetically active pigments in the equatorial Pacific. J. Geophys. Res. 102:12413-12423.

Arst H, Kutser T, 1994. Data processing and interpretation of sea radiance factor measurements. Polar Research 13:3-12.

Arst H, Nõges T, Nõges P, Paavel B, 2008. In situ measurements and model calculations of primary production in turbid waters. Aquat. Biol. 3:19-30.

Babin M, Stramski D, Ferrari GM, Claustre H, Bricaud, A, Obloensky G, Hoepffner N, 2003. Variations in the light absorption coefficients of phytoplankton, nonalgal particles, and dissolved organic matter in coastal waters around Europe. J. Geophys. Res. 108:3211.

Binding CE, Greenberg TA, Bukata RP, 2012. An analysis of MODIS derived algal and mineral turbidity in Lake Erie. J. Great Lakes Res. 38:107-116.

Bricaud A, Babin M, Morel A, Claustre H, 1995. Variability of chlorophyll- specific absorption coefficient of natural phytoplankton: Analysis and parameterisation. J. Geophys. Res. 100:13321-13332.

Bricaud A, Claustre H, Ras J, Oubelkheir K, 2004. Natural variability of phytoplanktonic absorption in oceanic waters: in- 
fluence of the size structure of algal population. J. Geophys. Res. 109:C11010.

Ciotti AM, Lewis MR, Cullen JJ, 2002. Assessment of the relationships between dominant cell size in natural phytoplankton communities and spectral shape of the absorption coefficient. Limnol. Oceanogr. 47:404-417.

Cleveland JS, 1995. Regional models for phytoplankton absorption as a function of chlorophyll a concentration. J. Geophys. Res. 100:13333-13344.

Dekker AG, 1993. Detection of optical water quality parameters for eutrophic waters by high resolution remote sensing. $\mathrm{PhD}$ Dissertation, Vrije Universiteit, Amsterdam.

Duyens LNM, 1956. The flattening of the absorption spectrum of suspensions, as compared to that of solutions. Biochim. Biophys. Acta 19:1-12.

Erm A, Arst H, Nõges P, Nõges T, Reinart A, Sipelgas L, 2002. Temporal variations in bio-optical properties of four North Estonian lakes in 1999-2000. Geophysica 38:89-111.

Ferrari GM, Tassan S, 1999. A method using chemical oxidation to remove light absorption by phytoplankton pigments. J. Phycol. 35:1090-1098.

Ficek D, Meler J, Zapadka T, Stoń-Egiert J, Woźniak B, 2012. Modelling of the light absorption coefficients of phytoplankton in Pomeranian lakes (Northern Poland). Fund. Appl. Hydrophys. 5:54-63.

Garver SA, Siegel DA, 1997. Inherent optical property inversion of ocean colour spectra and its biogeochemical interpretation. I. Time series from the Sargasso Sea. J. Geophys. Res. 102:18607-18625.

Gordon HR, Brown OB, Evans RH, Brown JW, Smith RC, Baker KS, Clark DK, 1988. A semianalytical radiance model of ocean colour. J. Geophys. Res. 93:10909-10923.

IOCCG, 2000. Remote sensing of ocean colour in coastal and other optically-complex waters. S. Sathyendranath (ed.). Reports of International Ocean-Colour Coordinating Group No. 3. IOCCG, Dartmouth: 140 pp.

ISO, 1992. Water quality - Measurement of biochemical parameters - Spectrophotometric determination of chlorophyll-a concentration. Norm ISO 10260:1992. International Organization for Standardization Publ., Geneva, Switzerland.

Jeffrey SW, Vesk M, 1997. Introduction to marine phytoplankton and their pigment signatures, p. 37-84. In: S.W. Jeffrey, R.F.C. Mantoura and S.W. Wright (eds.), Phytoplankton pigments in oceanography: guidelines to modern methods. UNESCO Publishing, Paris.

Kutser T, 1997. Estimation of water quality in turbid inland and coastal waters by passive optical remote sensing. PhD Thesis, Tartu University Press.

Kutser T, 2004. Quantitative detection of chlorophyll in cyanobacterial blooms by satellite remote sensing. Limnol. Oceanogr. 49:2179-2189.

Kutser T, Metsamaa L, Strömbeck N, Vahtmäe E, 2006. Monitoring cyanobacterial blooms by satellite remote sensing. Estuar. Coast. Shelf. Sci. 67:303-312.

Kutser T, Herlevi A, Kallio K, Arst H, 2001. A hyperspectral model for interpretation of passive optical remote sensing data from turbid lakes. Sci. Total. Environ. 268:47-58.

Laugaste R, Nõges T, Tõnno I, 2008. [Vetikad], p. 251-270. In: J. Haberman, T. Timm and A. Raukas (eds), [Peipsi].[Book in Estonian]. Eesti Loodusfoto, Tartu.
Laugaste R, Haberman J, Blank K, 2010. Cool winters versus mild winters: effects on spring plankton in Lake Peipsi. Est. J. Ecol. 59:163-183.

Laugaste R, Panksep K, Haldna M, 2013. Dominant cyanobacterial genera in Lake Peipsi (Estonia/Russia): effect of weather and nutrients in summer months. Est. J. Ecol. 62:229-243.

Le C, Li Y, Zha Y, Sun D, 2009. Specific absorption coefficient and the phytoplankton package effect in Lake Taihu, China. Hydrobiologia 619:27-37.

Lee ZP, Carder KL, 2004. Absorption spectrum of phytoplankton pigments derived from hyperspectral remote-sensing reflectance. Remote Sens. Environ. 89:361-368.

Lepane V, Leeben A, Malashenko O, 2004. Characterization of sediment pore-water dissolved organic matter of lakes by high-performance size exclusion chromatography. Aquat. Sci. 66:185-194.

Lohrenz SE, Weidemann AD, Tuel M, 2003. Phytoplankton spectral absorption as influenced by community size structure and pigment composition. J. Plankton Res. 25:35-61.

Longhurst A, Sathyendranath S, Platt T, Caverhill C, 1995. An estimate of global primary production in the ocean from satellite radiometer data. J. Plankton Res. 17:1245-1271.

Lorenzen CJ, 1967. Determination of chlorophyll and phaeopigments; spectrophotometric equations. Limnol. Oceanogr. 12:343-346.

Metsamaa L, Kutser T, Strömbeck N, 2006. Recognising cyanobacterial blooms based on their optical signature: a modelling study. Boreal Environ. Res. 11:493-506.

Morel A, Bricaud A, 1981. Theoretical results concerning light absorption in a discrete medium, and application to specific absorption of phytoplankton. Deep-Sea Res. 28:1375-1393.

Nõges P, Nõges T, 2012. Võrtsjärv Lake in Estonia, p. 850-861. In: L. Bengtsson, R.W. Herschy and R.W. Fairbridge (eds.), Encyclopedia of Lakes and Reservoirs. Springer Science+ Business Media.

Nõges P, Nõges T, Laas A, 2010. Climate-related changes of phytoplankton seasonality in large shallow Lake Võrtsjärv, Estonia. Aquat. Ecosyst. Health 13:154-163.

Nõges T, Nõges P, Laugaste R, 2003. Water level as the mediator between climate change and phytoplankton composition in a large shallow temperate lake Hydrobiologia 506:257-263.

Nõges T, 2001. Lake Peipsi. Meteorology, hydrology, hydrochemistry. Sulemees Publishers, Tartu: 163 pp.

Paavel B, 2008. Bio-optical properties of turbid lakes. PhD Thesis, Tartu University Press.

Pan X, Mannino A, Russ ME, Hooker SB, 2008. Remote sensing of the absorption coefficients and chlorophyll a concentration in the United States southern Middle Atlantic Bight from SeaWiFS and MODIS-Aqua. J. Geophys. Res. 113:C11022.

Partensky F, Hoepffner N, Li WKW, Ulloa O, Vaulot D, 1993. Photo-acclimation of Prochlorococcus sp. (Prochlorophyta) strains isolated from the North Atlantic and the Mediterranean Sea. Plant Physiol. 101:295-296.

Perkins M, Effler SW, Strait CM, 2014. Phytoplankton absorption and the chlorophyll a-specific absorption coefficient in dynamic Onondaga Lake. Inland Waters 4:133-146.

Seppälä J, Ylöstalo P, Kuosa H, 2005. Spectral absorption and fluorescene characteristics of phytoplankton in different size fractions across the salinity gradient in Baltic Sea. I. J. Rem. Sens. 26:387-414. 
Simis SGH, Peters SWM, Gons HJ, 2005. Remote sensing of the cyanobacterial pigment phycocyanin in turbid inland water. Limnol. Oceanogr. 50:237-245.

Smyth TJ, Moore GF, Hirata T, Aiken J, 2006. Semianalytical model for the derivation of ocean color inherent optical properties: description, implementation and performance assessment. Appl. Opt. 45:8116-8131.

Stomp M, Huisman J, Stal LJ, Matthijs HCP, 2007. Colorful niches of phototrophic microorganisms shaped by vibrations of the water molecule. ISME J. 1:271-282.

Stramski D, Morel A, 1990. Optical properties of photosynthetic picoplankton in different physiological states as affected by growth irradiance. Deep-Sea Res. 37:245-266.

Strömbeck N, 2001. Specific inherent optical properties of Swedish lakes and coastal waters. In: Water quality and optical properties of Swedish lakes and coastal waters in relation to remote sensing. Comprehensive Summaries of Uppsala Dissertations from the Faculty of Science and Technology, Uppsala.

Strömbeck N, Pierson DS, 2001. The effects of variability in the inherent optical properties on estimations of chlorophyll a by remote sensing in Swedish freshwaters. Sci. Total Environ. 268:123-137.

Stuart V, Sathyendranath S, Platt T, Maass H, Irwin BD, 1998. Pigments and species composition of natural phytoplankton populations: effect on the absorption spectra. J. Plankton Res. 20:187-217.

Stæhr PA, Markager S, 2004. Parameterization of the chlorophyll a-specific in vivo light absorption coefficient covering estuarine, coastal and oceanic waters. Int. J. Rem. Sens. 25:5117-5130.

Stæhr PA, Markager S, Sand-Jensen K, 2004. Pigment specific in vivo light absorption of phytoplankton from estuarine, coastal and oceanic waters. Mar. Ecol. Prog. Ser. 275:115-128.

Tassan S, Ferrari GM, 1995. An alternative approach to absorption measurements of aquatic particles retained on filters. Limnol. Oceanogr. 40:1358-1368.

Tassan S, Ferrari GM, 2002. A sensitivity analysis of the "Transmittance-Reflectance" method for measuring light absorption by aquatic particles. J. Plankton Res. 24:757-774.

Utermöhl H, 1958. [Zur Vervollkommnung der quantitativen Phytoplankton Methodik].[Article in German]. Verh. Internat. Verein. Limnol. 9:1-38.

Vaillancourt RD, Brown CW, Guillard RRL, Balch WM, 2004. Light backscattering properties of marine phytoplankton: relationships to cell size, chemical composition and taxonomy. J. Plankton Res. 26:191-212.

Westberry TK, Siegel DA, Subramaniam A, 2005. An improved bio-optical model for the remote sensing of Trichodesnium spp. blooms. J. Geophys. Res. 110: C06012.

Wetzel RG, Likens GE, 1991. Limnological analyses. SpringerVerlag, New York: 391 pp.

Yentsch CS, Phinney DA, 1989. A bridge between ocean optics and microbial ecology. Limnol. Oceanogr. 34:1694-1705.

Ylöstalo P, Kallio K, Seppälä J, 2014. Absorption properties of inwater constituents and their variation among various lake types in the boreal region. Remote Sens. Environ. 148:190-205.

Yoshimura K, Zaitsu N, Sekimura Y, Matsushita B, Fukushima T, Imai A, 2012. Parameterization of chlorophyll a-specific absorption coefficients and effects of their variations in a highly eutrophic lake: a case study at Lake Kasumigaura, Japan. Hydrobiologia 691:157-167. 